\title{
4 Trade, Territory, and Missionary Connections in the Sino-Tibetan Borderlands
}

\author{
John Bray
}

\begin{abstract}
The Missions Étrangères de Paris (M.E.P.) operated in the Sino-Tibetan border region of Kham between 1847 and 1952. The missionaries' prime objective was of course religious, but the division between spiritual and this-worldly aspirations was rarely straightforward. In practice they had to engage with secular rulers, if only to secure the political protection they needed to preach freely. Similarly, they could scarcely avoid entanglement in economic affairs, including trade. This essay discusses the M.E.P.'s involvement with trade as a means of shedding light on wider historical developments in the region in the second half of the nineteenth century.
\end{abstract}

Keywords: Kham, missionaries, Missions Étrangères de Paris, Tibet, trade

\section{Introduction}

In March 1848, a suspicious-looking trader turned up in the eastern Tibetan town of Chamdo. Uncertain of his identity, the Chinese civil mandarin summoned him for interrogation. In the face of detailed questioning, the stranger decided that he had no option but to admit that - contrary to his

Acknowledgements: I gratefully acknowledge the support of the staff of the Archives Diplomatiques de Nantes and the M.E.P. archive in Paris, especially the late Fr. Gérard Moussay, Brigitte Appavou, and Lucie Perrault. I thank Stéphane Gros and Yudru Tsomu for their helpful comments on an earlier draft of this paper.

Gros, Stéphane (ed.), Frontier Tibet: Patterns of Change in the Sino-Tibetan Borderlands. Amsterdam, Amsterdam University Press 2019

DOI: 10.5117/9789463728713_CHO4 
disguise as a Chinese merchant - he was a French national and that his 'trade consisted of selling, without money, the doctrine that leads to heaven'.

The 'trader' was Fr. Charles Renou (1812-1863), a Roman Catholic priest in the service of the Missions Étrangères de Paris (M.E.P.). On this occasion the Chinese authorities forced him to leave Chamdo and turn back to Guangzhou and then Hong Kong. However, he later succeeded in establishing a mission in the Tsarong region of southern Kham, under Lhasa's authority. His successors were expelled from Tsarong in 1865 but were later able to set up a chain of missions in the Sino-Tibetan border areas of Sichuan and Yunnan and maintained a presence there until 1952. Together with their Protestant counterparts, they spent longer periods in the region than any other category of Westerner. This extended engagement qualifies them both as 'participants', intensely involved in local affairs, and as 'observers' whose testimony constitutes a vivid and informative historical source for borderland history. ${ }^{2}$

Founded in 1658 , the M.E.P. was by the mid-nineteenth century enjoying a period of revival and growth. ${ }^{3}$ Its prime objective was of course religious: to share the 'doctrine that leads to heaven'. Indeed, the Monita ad Missionarios (Instructions to Missionaries), which were issued in 1665 and serve as one of the M.E.P.'s foundational texts, explicitly call on missionaries to avoid the slightest taint of commerce (Bousquet 2010, 180). However, the division between spiritual and this-worldly aspirations was rarely straightforward. In practice, M.E.P. missionaries had no choice but to engage with secular rulers, if only to gain access to land and to secure the political protection that they needed to preach freely. By the same token, they could scarcely avoid entanglement in economic affairs, including trade.

In this essay I adopt the theme of nineteenth-century French missionary involvement with trade as a 'prism' or 'lens' through which to shed light on wider historical developments in the Sino-Tibetan borderlands. The essay draws on original sources in the M.E.P. and French diplomatic archives, and is further informed by contemporary missionary publications as well as a range of more recent scholarship. ${ }^{4}$ To set the scene, I begin with a broad

1 Renou to M.E.P. Directors, 28 December 1848. Cited in Launay (1905, vol. 1, 81).

2 For a study of French missionaries' role as 'incidental ethnographers' in a neighbouring region, see Michaud (2007).

3 For a selection of recent reviews of the M.E.P.'s history, see Guennou (1986), Moussay (2008), and Marin (2010).

4 The most important of the missionary publications is Launay's two-volume, Histoire de la Mission du Thibet (1905). Launay was himself an M.E.P. priest. His work is scrupulously documented with references that can still be used as a guide to the M.E.P. archives. I have also 
review of power structures and trade networks in eastern Tibet before examining the M.E.P.'s experiences and observations in greater detail.

\section{The Setting: Interlocking Power Structures and Regional Trade Networks}

The M.E.P.'s engagement with Tibet came as a result of an appeal by Mgr. J.-L. Borghi, an Italian Capuchin bishop based in India who led the so-called Hindustan-Tibet Mission (Launay 1905, vol. 1, 65). In 1707 the Capuchins had established a mission in Lhasa, the capital of Tibet, but they were expelled in $1745 .{ }^{5}$ Ever since, they had retained formal ecclesiastical jurisdiction over Tibet but were short of resources in India, let alone north of the Himalaya. Knowing that the M.E.P. had established missions in Sichuan and Yunnan, Borghi suggested that it should take over responsibility for Tibet.

In 1846 the Vatican ratified this proposal with the establishment of the Apostolic Vicariate of Lhasa - also known as the Vicariate of Tibet - which was to be managed by the M.E.P. The vicariate was intended to cover the territories administered by Lhasa and, as will be seen, later came to include ethnic Tibetan regions in the Sino-Tibetan borderlands. In their writings the missionaries distinguished between 'the kingdom of Tibet' or 'Tibet proper' (Thibet proprement dit), meaning the territories controlled by the Ganden Phodrang administration in Lhasa; and 'Chinese Tibet', referring to the Tibetan chiefdoms or polities located in Sichuan and Yunnan. They rarely referred to 'Kham' except in discussions of the history and administrative structure of the region. ${ }^{6}$

At the outset, the M.E.P. was familiar with conditions in the main centres of Sichuan and Yunnan, but not with the border regions and still less with central Tibet. Their first challenge was therefore to understand the political landscape. As the M.E.P. quickly discovered, the Ganden Phodrang, the Tibetan administration in Lhasa, exercised a high degree of autonomy. Nevertheless, the Qing administration employed a parallel and overarching network of officials not only in Lhasa but also in regional centres such as

benefitted from more recent scholarship, especially Coleman (2014), Deshayes (2008), and Gros $(1996,2001,2016)$. See also my own earlier articles on the M.E.P. in Kham (Bray 1997) and on Christian missionaries and Tibetan trade (Bray 2014).

5 On the Capuchins' eighteenth-century mission in Lhasa, see Petech (1952-1957) and Engelhardt (2005).

6 For example, Desgodins discussed the eighteenth-century division of Kham province in a chapter on the geography of Tibet (Desgodins 1872,165 ). 
Markham and Chamdo. In its attempts to establish a foothold in Tibet, the M.E.P. would need to deal with both sets of officials. A similar pattern applied in the border regions of Sichuan and Yunnan where local chiefs enjoyed varying degrees of local autonomy while acknowledging the ultimate authority of the Emperor (see the Chronology of Major Events, this volume).

In their dealings with Tibetan and Qing officialdom, the M.E.P. would try to leverage their support of the French government. As will be seen, this approach was double-edged. Even the anti-clerical elements in the Paris establishment believed that Catholic missions could be a valuable instrument of French diplomacy. ${ }^{7}$ However, French government support would often fall short of the missionaries' expectations. A still greater problem was the Ganden Phodrang's fear of British expansionism from India. The M.E.P. missionaries emphasized that they were French, not British. The significance of this distinction was lost to many of their Tibetan interlocutors.

At the local level, overlapping political power structures were underpinned by an equally complex set of economic networks. As will be seen, the missionaries were to have no great difficulty in acquiring land to provide livelihoods for their followers, at least temporarily, because landholders were keen to encourage cultivators to settle in their regions. The greater problem was to establish a secure title to their land once they had acquired it.

For local landowners, the scarcest economic resource was not so much land as the labour needed to cultivate it. Taxes were paid in kind, in silver and through a variety of corvée labour obligations, especially transport labour. The difficulty of meeting these demands meant that it was all too easy for ordinary peasants to fall into debt to local landowners or to monasteries. Debt obligations could well lead to one of several different forms of servitude, including local forms of slavery (Gros 2016). Alternatively, peasants might flee the land altogether. In 1857 Renou wrote:

Taxes and corvée labour beyond the capacity of the people have obliged entire villages to leave their homelands, especially in Chinese Tibet, and the land has remained fallow. This class of men who have left their land have lost their civil rights. They form great bands of mendicants who travel in caravans, forcing villages to give them alms, and they are not without danger for the traveller who encounters them in the middle of the desert. ${ }^{8}$

7 On this point see Young (2013).

8 Renou to Count de Courcy, French chargé d'affaires in China at Macao, Tsarong, 26 July 1857. Archives Diplomatiques de Nantes (hereafter A.D.N.), Pékin 37. I am responsible for this and subsequent translations from the French. 
The missionaries believed that one of their key tasks was to protect their followers from this kind of fate.

Outside the monasteries, the majority of the region's inhabitants depended on a combination of agriculture and pastoralism, supplemented by trade. As in other regions on the edge of the Tibetan plateau, local and regional trade typically consisted of the exchange of salt, butter, and other produce from the higher regions in return for agricultural produce from the valleys. Trade was rarely 'free' in the sense that it was typically underpinned by a complex framework of labour obligations. To cite one example, also reported by Gros $\left(2016,15^{2}\right)$, Desgodins described how Tibetans from Tsarong exchanged salt for grain with the Nung, a non-Tibetan ethnic group in the neighbouring Salween valley (C.H. Desgodins 1872, 323). The Nung had to carry 500 to 600 loads of salt from Tsarong every year free of charge, and then exchange it at a pre-determined non-market rate of five loads of cereals for one of salt.

The most important long-distance trade was in tea along the route from Dartsedo via Lithang and Bathang to Lhasa. Tea was of considerable economic and strategic importance to the Qing authorities and to the trading houses (guozhang) of Dartsedo (Yudru Tsomu 2016). Many of the leading Buddhist monasteries served in effect as trading houses in their own right, although there was often an element of compulsion in their sales practices. As Bishop Félix Biet (1838-1901) noted in 1893:

With little respect for the law of supply and demand, the monastery is in effect able to impose the sale of its products on its clients, even against their will. When it has a stock of tea to place, it divides it among rich families in accordance with their wealth and obliges them to take delivery, either in cash or on credit. It is an obligatory purchase - but not free of charge (cited in Groffier 1893, 141).

However, as Renou reported in 1857 , tea was by no means the only medium and long-distance trade item:

English cotton goods are spreading more and more in Tibet. Crockery and many other European objects, introduced by the Nepalis above all, are beginning to present a considerable competition for China. For a long time India has supplied Tibet with pearls, coral and sea-shells. Russia also sends cloth there. ${ }^{9}$ 
Figure 4.1 Chinese coolies carrying tea to Dartsedo

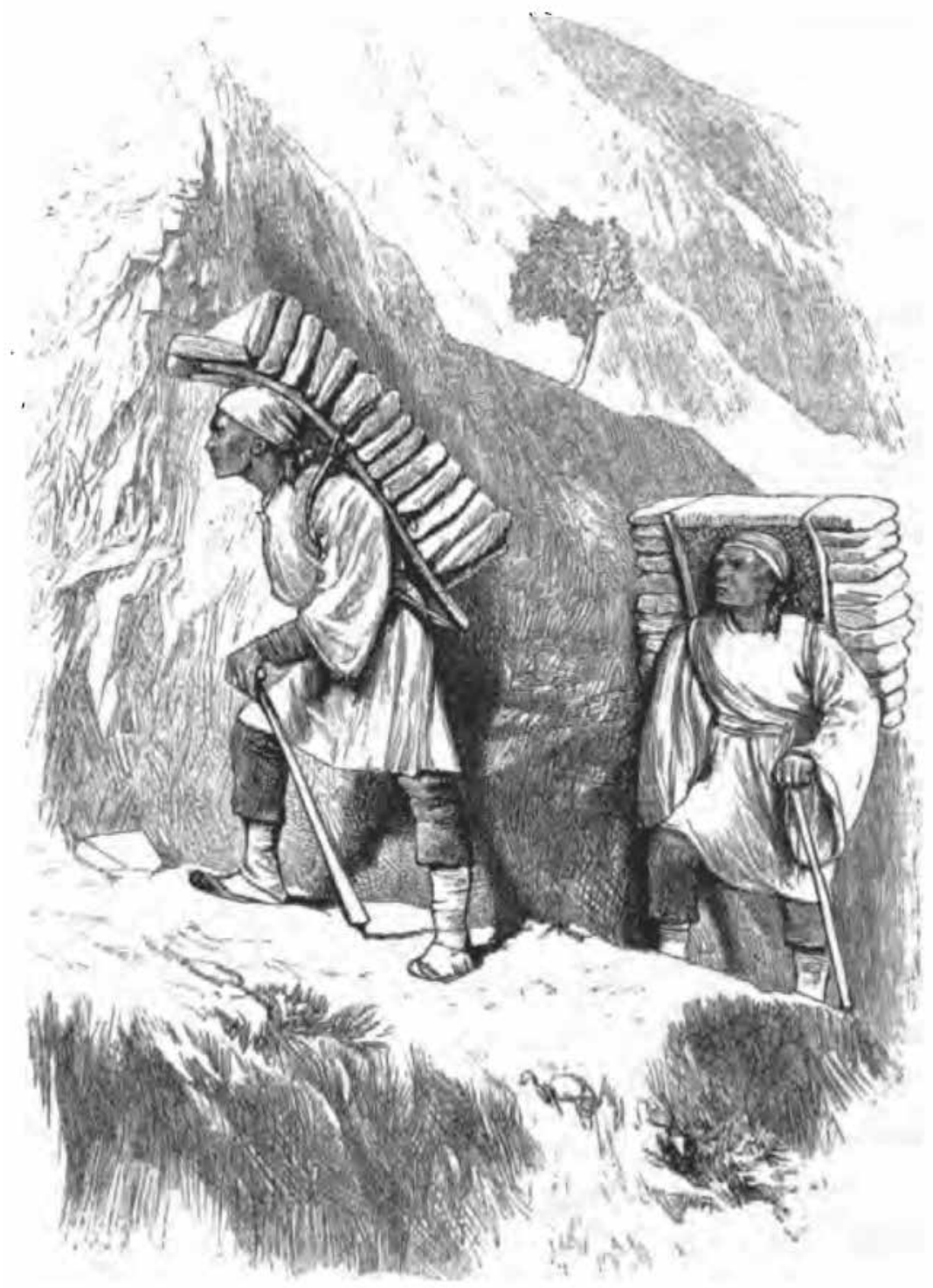

Source: Cooper $(1871,201)$ 
In the same letter, he noted that the British were also having an impact on the musk trade:

What was regarded as the best quality [of musk] was provided by savage tribes, situated to the east of Assam, among them the No-kong, who come each year to Dza-yul to exchange the produce of their country for cloth, chaudières ${ }^{10}$ and agricultural tools. However, since the English have become masters of Assam, these savages prefer European cloth and rupees, and they have begun to sell them their musk directly, and no longer bring so much to Tibet as in the past.

In the 1850 on and 1860 os most local and regional trade took place through barter. However, tea was also widely used as a form of currency, supplemented by silver. Since the early eighteenth century, the Chinese had imported silver often in the form of ingots - to pay its military garrisons in Lhasa and other towns along the main trade routes. Silver ingots were also in circulation in Tsarong in the 1850 s, and used to pay taxes although they were often in short supply. In later decades, as Relyea (2016) has pointed out, the circulation of British rupees increased enormously in Tibet and as far as western Sichuan.

Throughout the period under review, European economic influence was expanding, and this was an important part of the backdrop for the M.E.P.'s activities. At the same time, as pointed out by Yudru Tsomu (2016) and C. Patterson Giersch (this volume), indigenous Tibetan trading houses from Dartsedo and Chinese merchants from Shaanxi and Yunnan were expanding their own networks. The M.E.P. missionaries set themselves the task first of understanding these developments and then - where possible - turning them to the mission's advantage.

\section{Trade, Exploration and Information-Gathering}

When Renou began his explorations of eastern edge of the Tibetan plateau in 1847 , his immediate preoccupation was to work out where to establish the first missionary outpost. From the outset, he made a close study of Sino-Tibetan trade networks as a vital source of intelligence. In his travels, he chose the disguise of a trader because Christian missionary activity was still severely restricted in the interior of China in the 1840s. It would be going

10 The dictionary definition is 'boiler' or 'heater'. Here the word perhaps refers to pots and pans. 
too far to say that his disguise placed him beyond suspicion. The fact that he was able to attempt it at all testifies both to his Chinese language skills and to the rarity of Westerners in the Sino-Tibetan borderlands in that period.

At the outset, Renou argued that the M.E.P. should place a missionary in Dartsedo, which lay within the borders of Sichuan, because it would be the most favourable post for communicating with eastern Tibet. ${ }^{11}$ However, when he arrived there in September 1847, he noted the presence of a large number of Qing officials. He therefore travelled on to Bathang, and then via Markham to Chamdo, both of which lay within the territories administered by the Ganden Phodrang.

Renou's 1848 expulsion from Chamdo at the hands of a Qing official raised questions about the extent and nature of China's authority in Tibet (here referring to the territories administered by Lhasa). At this time Renou argued that if the Chinese could expel a Frenchman from Tibet, it would be necessary to 'accord them the same rights for the kingdoms of Ava, Siam, Cochin-China and others who are subject to them on the same footing as Tibet and Bhutan'. ${ }^{12}$ However, even with the support of the French legation, the M.E.P. was unable to persuade the Qing authorities to accept the argument that Tibet was in effect an independent country. The outcome was a diplomatic stalemate: the Qing administration gave no clear explanation of the nature of their political authority in Tibet. At the same time, they insisted that there was no possibility of Renou being allowed to return there. ${ }^{13}$

In late $185_{1}$ Renou once again disguised himself as a merchant to resume his explorations, this time from Yunnan. By April 1852, he reached the Dali region where he learnt of the regular Tibetan pilgrimages to Mount Jizu, known from its shape as the 'chicken foot mountain'. He also learnt of a local fair which was visited by Tibetan merchants in the third and ninth months of the Chinese lunar calendar. Renou sent two Chinese servants - likewise disguised as traders - on a reconnaissance of the Yunnan/Tibet borders. ${ }^{14}$ They brought back a favourable report, and he decided to follow the same route.

At this point, he sent a request to Rome asking for special dispensation to engage in trade in the light of the M.E.P.'s ban on commercial activity. ${ }^{15} \mathrm{His}$ plea was based on the argument that he needed trade goods to support his

11 Renou to M.E.P. Directors, 29 April 1849. Cited in Launay (1905, vol. 1, 74-75).

12 Renou to the French minister, Hong Kong, 14 December 1848. A.D.N. Pékin 37.

13 See Launay (1905, vol. 1, 88-97) for an account of the arguments on both sides. In Launay's view the outcome was not so much a stalemate as a defeat for French diplomacy.

14 Renou to Directors, Dali, 3 July 1852. Archive des Missions Étrangères de Paris (hereafter A.M.E.P.) 556 , p. 304.

15 Ibid. 
disguise as a merchant. Moreover, the regions in which he hoped to travel were scarcely monetized and most exchanges therefore took the form of barter. Communications with Europe were slow: it would have taken several weeks for Renou's letter even to reach the Chinese coast. Rome eventually granted Renou's request, although he did not receive the confirmation until well after his return to Dali. ${ }^{16}$

On September 1852, Renou set out again, accompanied by a small group of Chinese Christians. A few weeks later, he arrived at the monastery of Döndrupling, where he displayed the goods that he had to sell, mainly cloth. One of the more unusual items in Renou's baggage - a telescope - piqued the curiosity of the monastery's incarnate lama. Renou at first explained that the telescope was not for sale, but then agreed to offer it in exchange for Tibetan lessons. ${ }^{17} \mathrm{He}$ subsequently spent ten months studying at the monastery. He did not fit the characteristic mould of a Chinese trader because - while it was understandable that he might wish to learn spoken Tibetan - it was more unusual that he wished to study Tibetan written texts, and even the niceties of Buddhist philosophical terms. However, it seems that he was not identified as a European, at least not conclusively.

After returning to the Dali region, Renou outlined his proposal to establish a foothold in territory under Lhasa's administrative control in a letter to Paris in February 1854. Among other details, he proposed to engage in a different kind of trade: the purchase of child slaves in order to bring them up in the Christian faith. ${ }^{18}$ He noted that the 'misery that reigns in the lower classes' meant that parents were frequently obliged to sell their children to pay their debts. In the future such children could serve the mission by sharing their faith with their compatriots.

In March 1854, Renou set out again. This time his route took him to the monastery of Changputong on the bank of the upper Salween River, where he again made friends with the incarnate lama. He stayed for another three months, continuing his study of Tibetan, but still in his guise as a merchant:

As for my trade, the pretext for my stay in Tibet, this was easy to conduct because the lama, while saying nice words to us, prevented his subjects from buying or selling anything, whatever it might be, reserving the monopoly for himself in the belief that it must be very profitable for him.

16 See Launay $(1905$, vol. 2, 394) for the Latin text of the decision by the Propaganda Fide, dated 4 May 1853.

17 Renou to the M.E.P. directors, 3 December 1852. Cited by Launay (1905, vol. 1, 206-207). 
Poor lama! Prophet though he claimed himself to be, he scarcely perceived what kind of trade I had come to conduct in his country! ${ }^{19}$

Here he heard of possible land to rent on the far side of the river, just inside the Tsarong district of Tibet proper. Making the acquaintance of Tsewang, one of the richest people in the region, he agreed to lease land in Bonga. Bonga was not a mere patch of land but an entire valley. In the past it had been cultivated by Nung farmers, and had produced good harvests of wheat. However, they had been forced to cede the land because of heavy debts to Tsewang, and had ultimately withdrawn, leaving the land uncultivated.

\section{A Foothold in Southern Kham}

Renou's acquisition of land in Tsarong meant that he had at last established a base in 'the kingdom of Tibet': Tsarong was in the district of Menkong which was itself part of a wider region administered from Markham within the part of Kham under the authority of Central Tibet. In Markham there was a small Qing military garrison. Ironically, in view of subsequent events, Renou at first believed that he was safer in Tsarong than in China where Christianity was still officially forbidden. ${ }^{20}$ The Chinese legal code did not extend as far as Tibet and, according to Renou, no one had thought of banning Christianity there.

Renou had also crossed the boundary from being a pretended merchant to becoming a farmer. At the same time, he changed from being a mere observer of Tibetan life to becoming a full participant, including in local trade. He of course brought with him the attitudes and aspirations of a European outsider, and a Catholic missionary at that. However, in putting his plans into practice, he had to adapt to the social as well as the geographical constraints of the environment in which he worked. It would be too much to claim that he became in any way 'Tibetan'. However, his overall approach may have been more indigenous than he himself realized.

Having acquired the land, Renou now had to consider the greater challenge of securing an adequate labour supply. He addressed the problem in three ways. First, he imported labourers from Yunnan: these included Chinese Christians who were to form the core of the new community, as well as craftsmen who would help construct the mission buildings. Secondly, as

Renou to Count de Courcy, 26 July 1857. A.D.N., Pékin 37. 
he had planned, he purchased orphans with a view to building up a Christian community for the future. Thirdly, he hired labourers from the local villages to clear trees to make room for cultivable land. Meanwhile, he was joined by a fellow-missionary, Jean-Charles Fage (1824-1880).

The missionaries also needed to buy necessities such as grain, salt, and butter, and this was another important point of contact with neighbouring villages. In the first instance they paid for these goods by bartering cloth and other trade goods from Yunnan. However, as Renou explained, there was a local shortage of silver, which was needed to pay taxes. The result was that their neighbours were reluctant to supply the missionaries and their followers unless they gave silver in return. ${ }^{21}$

In 1857, encouraged by Renou's reports of the new missionary outpost in Bonga, the M.E.P. appointed Jacques Thomine-Desmazures (1804-1869) to serve as the first Bishop of Tibet. It also sent a group of younger missionaries to serve as reinforcements. However, the mission did not develop as they had hoped. In September 1858 Tsewang announced that he wished to regain possession of Bonga, and turned up with a band of thugs to expel the missionaries. This episode set in motion a chain of events that brought the mission to much greater official attention in both Lhasa and Beijing. ${ }^{22}$

According to Fage, economic considerations were among the factors leading to attacks on the mission:

I am convinced that we would not have been attacked if our financial resources had permitted us to continue our trading, especially at a time when silver is very rare in Tsarong. The people who earlier found silver only in Bonga would not have wished to oppose us, in the hope that they would still have the means through us to pay their taxes and debts. Only, we had almost no silver left - approximately 200 taëls at the beginning of $1858 .{ }^{23}$

At this point, Thomine-Desmazures decided that it was time for the mission to adopt a much more public stance and to seek overt French diplomatic support. An important factor in this decision was Article 8 of the 1858 Treaty of Tianjin, which declared that Christian missionaries were entitled to the protection of the Chinese authorities. Contrary to their earlier argument that Tibet enjoyed a similar status to Siam, the M.E.P. now argued that it

21 Renou to Libois, 20 August 1856. Cited by Launay, (1905, vol. 1, 51).

22 See Launay (1905, vol. 1, 316-383) and Deshayes $(2008,57-64)$ for more detailed accounts. See also Gros (1996) and Bray (1997).

23 Fage to Libois, 8 August 1859. Cited in Launay (1905, vol. 1, 317). 
was directly subject to Chinese rule. Missionaries therefore enjoyed the same right to Chinese protection in Tibet as they did in China proper. In pursuit of this claim, and flying the French flag as a mark of official status, Thomine-Desmazures marched via Dartsedo and Markham to Chamdo.

During this period, Thomine-Desmazures sent two Chinese Christian merchants to Lhasa to prepare the way for the missionaries (Launay 1905, vol. 1, 371). However, the Ambans expelled them on the grounds that, since they were Christians, they must be in contact with the French and the British. They were forced to leave the capital before they had had an opportunity to sell their merchandise, and they suffered a loss of 2,00o taëls.

In Chamdo the missionaries negotiated with representatives from the Lhasa and the Qing administrations while drawing on long-distance support from the French legation in Beijing. The eventual outcome in 1862 was that the Qing and Tibetan authorities formally acknowledged the M.E.P.'s title to Bonga, and even promised to punish Tsewang for his aggression. However, the missionaries were obliged to accept that they could not now travel to Lhasa, ostensibly because it was not safe to do so. It was clear that the assent of both the Qing and - still more - the Lhasa authorities was at best lukewarm.

In the short term the perception that the missionaries had access to political as well as spiritual power contributed to a series of conversions first of the entire village of Songta close to Bonga, and then of a series of other villages and hamlets. However, such interventions threatened to disrupt local religious and political power structures. The missionaries forbade their converts to make grain contributions to local monasteries, to whom they were often in debt, in return for their prayers. In 1863 the monastery of Menkong responded by demanding immediate repayment of an enormous debt from the recently Christianized village of Aben (Launay 1905, vol. 1, 401).

Renou's death in late 1863 deprived the mission of its most forceful leader at a time when it had become acutely vulnerable. In 1864 a decree issued with the Dalai Lama's seal stated that Lhasa had learnt that the religion of the heretics (mou-ti-pa in the French transcription, probably mutekpa) had been introduced in the region: local officials and monasteries were charged with stamping it out. ${ }^{24}$ The ultimate outcome was that in 1865 , the missionaries were forced to leave Tibetan territory altogether, along with the followers who remained loyal to them. One of the missionaries, Gabriel Durand (1835-1865) was killed, as were several converts.

In their analysis of these events, the M.E.P. complained that the French legation in Beijing failed to give them the wholehearted support that they 
had hoped for. ${ }^{25}$ This complaint was partially justified inasmuch as the legation judged that the Qing authorities in practice exercised limited authority in Tibet, particularly on religious matters. It was therefore both impolitic and impractical to press them too far. The M.E.P.'s argument was now that the Qing had both the authority and the power to protect the missionaries inside Tibet proper, but chose not to do so.

\section{Regrouping in Sichuan and Yunnan}

After their expulsion from Tsarong, the M.E.P. missionaries regrouped in the border regions of Sichuan and Yunnan. In December 1865, Bishop Joseph Chauveau (1816-1877), who had now taken over the leadership of the mission, reaffirmed that the Apostolic Vicariate of Lhasa extended as far as the borders of Kashmir (Launay 1905, vol. 2, 21). However, for the time being, he forbade his missionaries to enter 'Tibet proper'. Instead, while waiting for happier days, they should establish themselves as firmly as possible 'in the country where Chinese authority exercises a more or less decisive influence' (ibid.). He therefore applied to the Vatican for the formal transfer to the Tibet vicariate of fourteen 'principalities' from Sichuan, including Bathang, Lithang, and Chakla (including Dartsedo); as well as four 'towns' from Yunnan, including Adunzi (Deqin). In 1868 the Vatican duly gave its assent (Launay 1905, vol. 2, 29, 396) (see Map 4.1).

The M.E.P's strategy of appealing for the Qing government's protection was based on the Treaty of Tianjin. However, in the borderlands as in 'Tibet proper', the missionaries needed to deal with parallel and often overlapping authorities. In practice, the power of local Qing officials was constrained by poor communication lines to the main centres of authority in Chengdu and Kunming (then known as Yunnanfu), let alone Beijing. Meanwhile, indigenous rulers continued to exercise a high degree of local autonomy, although their positions and status were now formally confirmed by the Qing. The two depas of Bathang are an example. In 1648 the Fifth Dalai Lama appointed the original holders of these posts to collect taxes for a fixed three-year term (Coleman 2014, 49). However, their positions soon became hereditary and, by the time the M.E.P. entered the region, they stood at the apex of a local hierarchy of Kham Tibetan aristocrats whose status was likewise hereditary. The depas had their own trading interests which were supported by rights to corvée labour.

25 I discuss the issues in greater detail, drawing on French diplomatic archives, in Bray (1997). See also Launay (1905, vol. 2, 31-66) and Deshayes (2008, 64-73). 
Map 4.1 The principal M.E.P. mission stations in the Sino-Tibetan borderlands, c. 1900

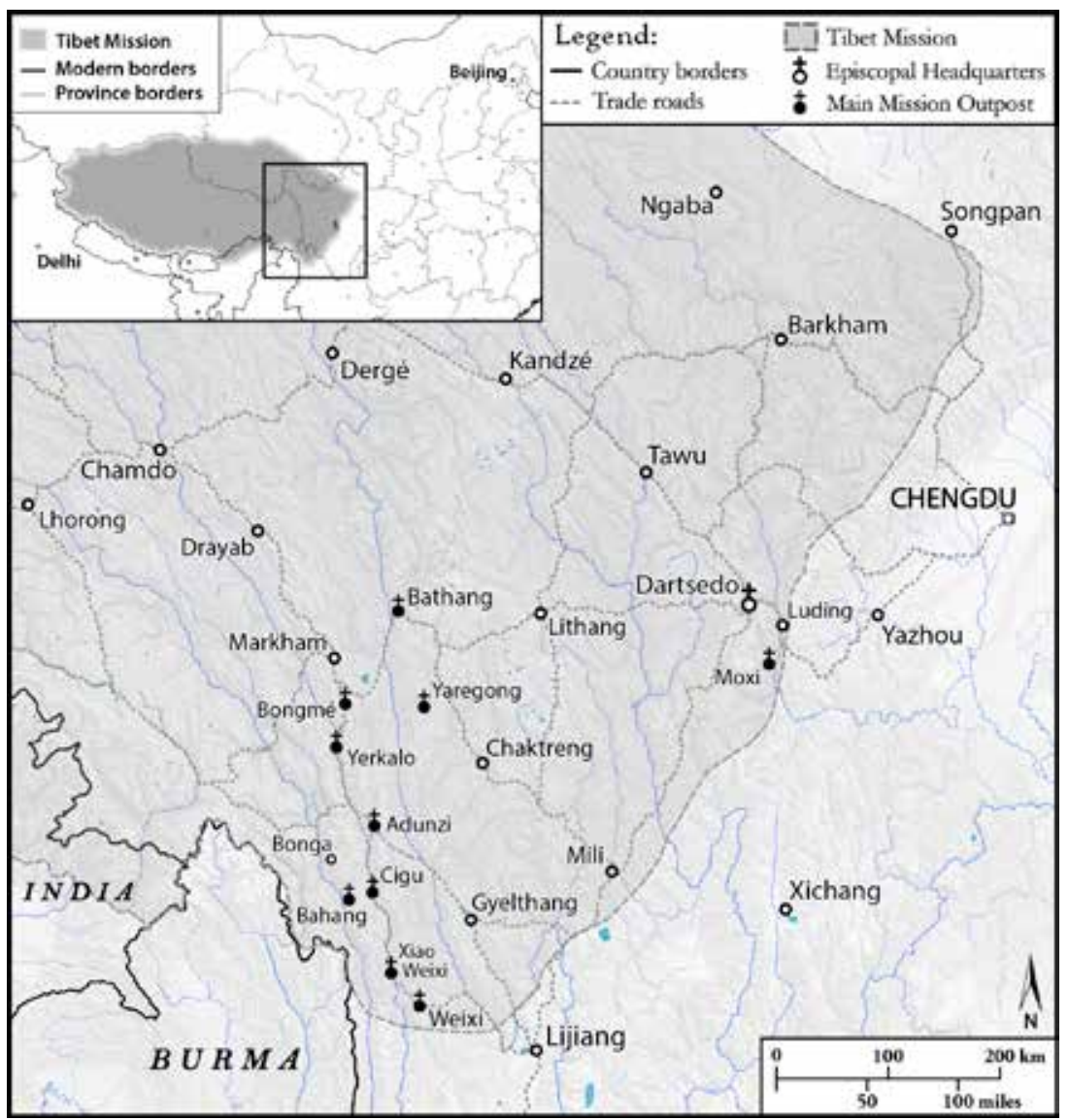

Sources: Based on Desgodins (1872); Launay (1905); SRTM (NASA) and modern administrative borders extracted from GADM database (www.gadm.org, v.2.5 July 2015)

Authors: Rémi Chaix and John Bray

The role of the Buddhist monasteries was a further complicating factor. Again, Bathang is an example. Ba Chöde was the leading local monastery. Since the mid-seventeenth century it had belonged to the Geluk and was therefore closely aligned with Lhasa spiritually and politically. It was also a major regional landowner, possibly administering as much as 40-50 per cent of land in the Bathang district (Coleman 2014, 33, 36-37). Like the depas, the monasteries had their own trading interests.

For the M.E.P. good lines of communication were as important as ever, and Chauveau established his headquarters in Dartsedo because of its status as a 
regional trading centre. For similar reasons, the M.E.P. established outposts at Bathang and at Adunzi in the same period. However, the majority of their stations were more agricultural in nature. Beyond their primary religious objectives, the missionaries' main preoccupation was to provide security and livelihoods for their followers. In this phase of their activities, they no longer needed to disguise themselves as traders or to undertake major trading activities in their own right. However, they continued to depend on regional trading networks for their own logistical support. At the parochial level, their role was to create a secure environment where their followers could engage in local trade as a supplement to their farming. In this they were partially successful, but life remained precarious for their Christians converts, as it did for their Buddhist neighbours.

Yerkalo serves as an example of the challenges. Then lying just inside Sichuan on the slopes above the banks of the river Mekong, Yerkalo is known in Chinese as Yanjing (literally 'salt well') and famous for its salt production, a prime trade item. ${ }^{26}$ The Catholic parish there was originally founded by Biet and Auguste Desgodins (1826-1913) following their expulsion from Tsarong. In 1870 they were able to acquire some abandoned fields in Yerkalo on a $5^{0}$-year rent. ${ }^{27}$ They and their successors gradually built up the settlement so that by the 1880 s it amounted to a substantial Christian village consisting of 21 families (104 people), together with 21 houses as well as stables and barns. ${ }^{28}$

In principle, the salt trade should have been a source of wealth in good years, and an economic safety net in years when harvest yields were poor. However, in practice many of Yerkalo's inhabitants endured no more than a precarious existence. In part this is because of the conditions under which salt was traded. Every year each of the two Bathang depas sent four official salt collectors to the region (Soulié 1904, 103). They had the right to free accommodation and sustenance during their stay of two to three months, and the local people had to carry the salt free of charge to Bathang. In addition, the officials compelled people to buy tea at three to four times the market price. The economic benefits of the salt trade therefore accrued not so much to the local inhabitants as to regional officials. The nineteenth-century village traders of Yerkalo were far from having the economic power of the midtwentieth-century Khampa traders described by Lucia Galli (this volume).

26 Due to twentieth-century boundary changes, Yerkalo now falls within the Tibet Autonomous Region and is no longer part of Sichuan. For an account of the techniques of salt production, see Desgodins (1872, 293-297).

27 Francis Goré (1880-1954). A.M.E.P. Typescript papers. Une mission thibétaine (Yerkalo). Éphémérides de Notre Dame de Sacré-Coeur 1865-1922.

28 Ibid. 


\section{Advocating British Indian Trade with Tibet}

Already in 1865 , feeling 'abandoned' by the French mission in Beijing, Desgodins had suggested that the M.E.P. should seek aid from the British. ${ }^{29}$ Later on, he and other missionaries suggested that the British might be instrumental in opening up Tibet, either through political or military means, or through trade. They therefore took all possible opportunities to lobby the British on the benefits of commercial engagement with Tibet.

One such opportunity came in 1868 , when a young Englishman called Thomas Thornhill Cooper (1839-1878) travelled to Dartsedo and Bathang. Cooper claimed to be acting on behalf of the Shanghai Chamber of Commerce, which was interested in potential new trade routes in southwest China, and he hoped to travel via Lhasa to India or, alternatively, to travel south via Adunzi to Burma. Cooper benefited from the M.E.P.'s logistical network at every stage of his journey. For example, while still travelling up the Yangtze, he mentions meeting a 'Catholic Mission Agent', whom he describes as a wealthy merchant engaged in an extensive trade with Sichuan (Cooper 1871,39). He needed to deal with this merchant to arrange funds for his onward journey to Chongqing.

Similarly, in Bathang Cooper mentions that he met a Chinese merchant who was 'the writer, or chief man of business of the missionaries' (Cooper 1871, 261). Together with his brother, this man had owned a 'drug shop' in Lhasa, but they had been expelled because they were Christians. Cooper does not mention this man's name, but he may have been one of the two merchants whom Thomine-Desmazures had sent to Lhasa in 1862. Apparently, he hoped that Cooper would indeed travel to Lhasa, where he would be arrested and maltreated by the Tibetan authorities. This in turn would provoke British intervention which would benefit the mission and at the same time enable him to recover his business. In the event, Cooper disappointed the merchant by travelling to the south instead of via Lhasa. However, he was forced to turn back before he could reach Dali, let alone the Burmese border. Despite this defeat, he was full of praise for the M.E.P. missionaries who had assisted him throughout his journey.

While still en route, Cooper (1868) wrote a letter to the Royal Geographical Society in London, including a set of 'Notes on Thibet, by a French missionary', probably Desgodins. This includes a discourse on the prospects for sales of Indian tea in Tibet. Cooper returned to this topic in his subsequent book, noting the likelihood of political opposition from the Chinese authorities and the Tibetan monasteries: 
Figure 4.2 Tibetan Inn in Dartsedo

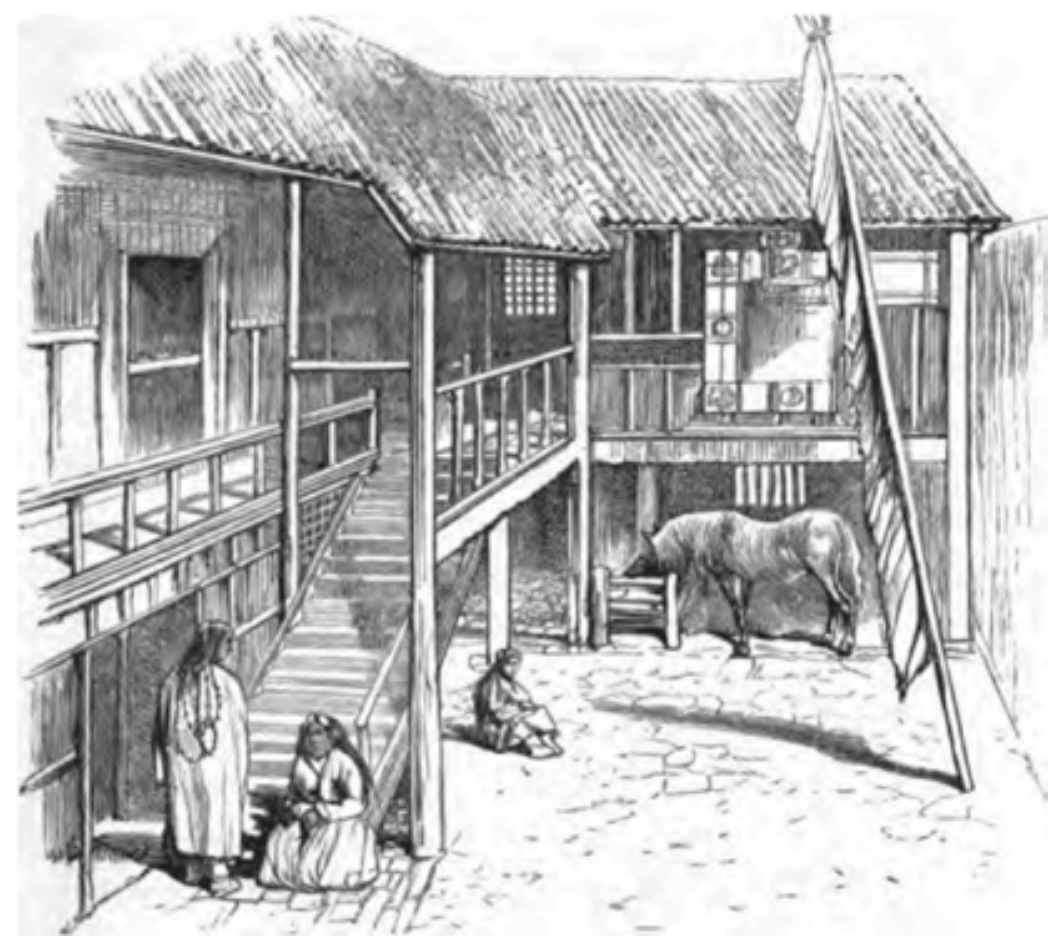

Source: Cooper $(1871,204)$

The Chinese on their part dread the loss of their valuable wholesale monopoly, to maintain which they give the Lamas the monopoly of the retail supply; who by this means, hold in absolute subjection the people, to whom tea is a prime necessity of life. The Lamas, on their part, fear that with the introduction of British trade, the teachers of the new religion would come, and free trade and free thought combined would overthrow their spiritual sway (Cooper 1871, 263).

The book concludes with a memorandum by 'an old resident in China', almost certainly a French missionary. This pays tribute to England as 'the only power on earth sufficiently rich and strong enough to rely together China, Thibet and India', and calls for the establishment of English factories (i.e. trading posts) in Lhasa, Bathang, Dali, and Chongqing.

The M.E.P. likewise offered practical assistance to Captain William Gill (1843-1882), a second British traveller, who travelled to Dartsedo in 1877 
and - unlike his predecessor - succeeded in making the overland journey to Burma. For example, Gill notes that the missionaries helped him gather a supply of British Indian rupees, which were the most convenient currency in southwest China and Tibet: ${ }^{30}$

At the time of our visit, we found it difficult to obtain a large number of rupees; for the embassy that had just arrived from Peking, and was on its way to Lassa, had bought them all up; but Monseigneur Chauveau contrived to find ten thousand for us among his friends and acquaintances. (Gill 1883, 171)

In 1878 , a third British traveller made his way to Dartsedo. This was Edward Colborne Baber (1843-1980), an official in the China Consular Service. According to Launay (1905, vol. 2, 143-145), Baber hoped to become the official British Resident in Lhasa. In pursuit of this ambition, he was assiduous in collecting economic information, and repeatedly plied Biet with questions on the price of tea and cloth in local markets. Although Baber's report makes no reference to M.E.P. sources, it repeats many of the same arguments that they had put forward:

To the Tibetan, tea is more than a luxury, it is an absolute necessary. Deprived of the costly, but indispensable, astringent, he suffers from headache, grows nervous, restless, out of condition, and altogether unhappy. (Baber 1882, 198)

In 1880 Biet sent Desgodins to India where he eventually established an outpost of the mission at Padong, near Kalimpong and close to the southern borders of Tibet. In 1883, in response to a request from the M.E.P., the Vatican formally attached the eastern part of Darjeeling district to the Tibet vicariate (Launay 1905, vol. 2, 184, 404). It also included the Chumbi valley (an outpost of Tibetan territory between Sikkim and Bhutan) and Tawang (now in the Indian state of Arunachal Pradesh but claimed by China). From Desgodins' perspective the references to Chumbi and Tawang were welcome but not strictly necessary because these were in any case part of Tibet and therefore within the mission's original mandate.

Desgodins made extensive contacts in British official circles and published a pamphlet on A Tea Trade with Thibet at the expense of the Bengal Government Secretariat. Writing as though from a British perspective, Desgodins argued that there was an 'export tea market at our doors'. The 
pamphlet goes into some detail on the different types of tea and how they are made. It also discusses the political economy of the trade, including the role of officials acting in a private capacity, and taking advantage of corvée labour:

When Chinese mandarins in charge of the troops and of the Lamas' pay [italics in the original] receive their allowance, they generally expend at Ta-tsien-loo [Dartsedo] part of the money entrusted to them in buying tea. This tea is conveyed at the expense of the people, as extra duty, and given as pay to the soldiers, and even to the Lamas, at the price current in the interior, according to the place. The conveyance having cost nothing, and the price being threefold or fourfold higher than at Ta-tsien-loo, the mandarins realise by this means considerable profits for themselves, in which the Government does not participate. (Desgodins c.1881, 13)

The pamphlet concludes by expressing the view that the tea trade might be the means by which 'the people of Thibet would learn to appreciate and wish for the more enlightened rule with which India is blessed' (Desgodins c.1881, 14). However, on a strictly practical note, he argued that success could only be achieved 'by offering to our customers what they want: tea prepared to suit their tastes' (Desgodins c.1881, 16).

Desgodins' recommendation that Indian tea planters should provide Tibetan customers with what they wanted seems obvious but it was never achieved. The Chinese authorities continued to oppose the Indian tea trade, but their objections were not the only obstacle. The Tibetans did not like the taste or quality of Indian tea and, as Booz (2011) points out, British tea planters had little enthusiasm for the Tibet market. Sales to England were expanding in any case, and there was therefore little incentive to embark on an alternative project that seemed new and strange. Desgodins and his colleagues hoped that Catholicism would follow Indian tea into Tibet. This never happened.

\section{Local Repercussions of International Rivalries}

In 1887 the M.E.P. faced a fresh outbreak of persecution. The epicentre was at Bathang..$^{31}$ The first major sign of trouble came in May when a crowd

31 This episode is discussed at some length, with copious quotations from original correspondence, in Launay (1905, vol. 2, 220-255). See also Deshayes (2008, 102-104). 
threw stones at the missionaries' residence, causing considerable damage. ${ }^{32}$ Tensions continued to build up over the following weeks, and in July a crowd of about a hundred peasants launched a full-scale attack on the residence. The two M.E.P. missionaries, Pierre Giraudeau (1850-1941) and Jean Soulié (1858-1905), found refuge first in the house of the second depa and then with the first depa. On 1 August they fled from Bathang and eventually reached safety in Dartsedo.

In the M.E.P.'s analysis a combination of local and international factors had prompted the attacks. In their view, the root cause was the 'hatred of the lamas', specifically the lamas of Lhasa. ${ }^{33}$ For example, they cited a set of letters issued by the 'king of Lhasa' and the three great monasteries of Lhasa that condemned Christianity and was explicitly addressed to the chiefs, monasteries, and people of Bathang (Deshayes 2008, 321-326). The secondary cause was the Government of India's decision to withdraw plans for an expedition to Lhasa to be led by the British official Colman Macaulay (1849-189o) with a view to promoting trade with Tibet. ${ }^{34}$ The Lhasa monks were strongly opposed to the proposed mission and took the decision to cancel it as a sign of weakness. Having seen off a potential British threat to the south, they believed that they could now turn their attention to the French in Kham.

At the local level, the missionaries believed that a combination of factors were in play. Their main enemy was the Ba Chöde monastery, acting on instructions from Lhasa. The people who actually attacked them were detsodunpo ('people of the seven districts'), villagers who were clients of the monastery and obeyed its orders. The assault on the mission was therefore far from spontaneous. The missionaries believed that the Qing mandarin in Bathang had the authority to stop the attacks but, motivated by a 'deaf jealousy' of the mission, had deliberately failed to do so. ${ }^{35}$ Meanwhile the two depas were caught between opposing forces, ostensibly sympathetic to the missionaries' plight, but ultimately unable to protect them.

The M.E.P. posts in Yaregong and Yerkalo - both in the Bathang domain also came under attack, and the missionaries in these stations were forced to

32 Giraudeau and Soulié to Biet, Dartsedo 1 September 1887, cited in Launay (1905, vol. 2, 228-233).

33 Procès de la Mission Catholique Française au Thibet chinois, 2 November 1893 A.D.N. Pékin

34 On Macaulay see Singh $\left(1988,205^{-210}\right)$.

35 Drawing on Qing sources, Coleman (2014) presents a rather different view of local Qing officials' position, emphasizing that their authority was far from absolute, and that they in practice needed to negotiate with local Tibetan interests in order to achieve their objectives. 
Figure 4.3 Bathang, early twentieth century

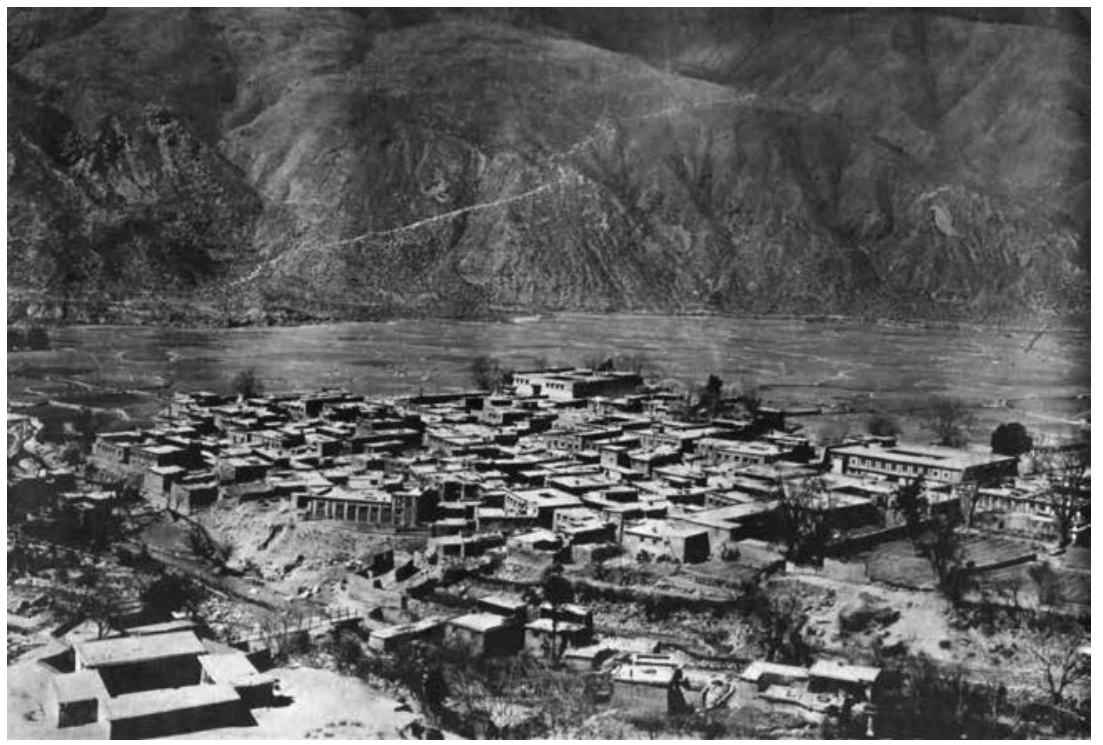

Source: M.E.P. archives, Paris

flee with their followers. In Yunnan, monks in Adunzi monastery, apparently acting in collusion with their counterparts in Bathang, likewise destroyed the local mission station. At the same time, Etienne Dubernard (1840-1905) and some 300-400 Christians were forced to flee from the nearby station of Cigu (Tsekou).

\section{Appeals to French Trading Interests}

Over the next ten years the energies of Bishops Biet and Giraudeau, who was appointed coadjutor in 1892, were almost fully taken up with the demand for reparations for the destruction of the missions. The French legation in Beijing was broadly supportive of the M.E.P. but did not always act with the alacrity that the missionaries wished.

In November 1893, hoping to boost French diplomatic support, Biet wrote a brief on the 'Industrial and commercial advantages for France prepared by the French Catholic mission'. ${ }^{36}$ The brief starts by reviewing British and Russian commercial initiatives in the region, and then points out that 
the only gateway to Tibet from Yunnan and the French colony in Tonkin would be Adunzi, a town occupied by French missionaries for 30 years. The inhabitants of the mountains and valleys regarded the French as 'friends and liberators' because of the missionaries' work in vaccinating them against smallpox. ${ }^{37}$ Dartsedo would be an alternative gateway from Sichuan and, there too, the French were held in high regard:

At very short notice, industrial and commercial France will be able to reap the benefits of the installation of her missionaries in Tibetan territory for 30 years; and the French missionaries of Tibet will always make it a pleasure and a duty to assist with the development of French influence and interests in any way possible. ${ }^{3}$

He then presented a long list of Tibetan exports including wool, yak leather, animal skins, and musk. In return the Tibetans would be pleased to purchase red, purple, and green cloth, cotton goods, camphor, aloes, quinine, knives, scissors, mirrors, musical boxes, stereoscopes, dolls, drugs, telescopes, binoculars, watches, kitchen clocks, and bridles for horses.

The M.E.P. received strong support from Frédéric Haas (1843-1915), a French diplomat who in the early 1890 s served as consul in Hankou (Bensacq-Tixier 2003, 290-294). Haas was an enthusiastic proponent of French commercial expansion, including the development of a commercial route as far as the borders of Tibet. In June 1894, Haas wrote to Biet pledging his personal devotion to the mission in his capacity as a man of faith as well as a French patriot ${ }^{39} \mathrm{He}$ recommended that, in the interests of the mission, Biet should appeal to French commercial as well as political interests. In a subsequent letter, he went so far as to offer to lead an official French mission to Bonga, and suggested that the missionaries should accompany the mission as interpreters. ${ }^{40}$ The Chinese could scarcely object to an official French mission of this nature and, having reached Bonga, the M.E.P. would then be able to take repossession of their former post.

The French expedition to Bonga never took place. However, in late 1895 Haas was appointed to serve as the first French consul of Chongqing. From there he continued to promote the idea that Yunnan qualified as the

37 As early as 1854 , Renou had written to his colleagues to apply for a supply of smallpox vaccine. Renou to Libois, 31 January 1854, A.M.E.P. 556a, 477-483.

38 Biet, Procès de la Mission Catholique Française au Thibet chinois, 2 November 1893, A.D.N.

39 Haas to Biet, 5 June 1894. A.M.E.P., 556G, 841-848.

40 Haas to Biet, 19 June 1894 . A.M.E.P., 556G, 849-856. 
commercial 'hinterland' of the French colonial possessions in Tonkin. This idea attracted a degree of support from the French colonial authorities in Tonkin, but the French never developed significant commercial interests in Tibet.

Nevertheless, Auguste Gérard (1852-1922), the French minister in Beijing, continued to give the M.E.P. political support. In 1897 he ordered Haas to travel in person to Chengdu to take up the missionaries' cause there (Launay 1905 vol. 2, 317). If necessary, he was to accompany the missionaries in person to Bathang. As noted above, Haas never went that far, but it seems that this threat of intervention at last galvanized the Sichuan authorities into taking action. They appointed Ji Zhiwen, a former Bathang civil mandarin, to take up the M.E.P.'s case. Ji quickly reached an agreement with the two depas and the Ba Chöde monastery facilitating the missionaries' return in May 1897, while offering them financial compensation.

A final settlement to the Bathang affair was signed by the two Bathang depas and the head of the Ba Chöde monastery in February 1900 (Launay 1905, vol. 2, 328-330). The settlement confirmed that Bathang natives would have all freedom to become Christians. Those who were already required to pay tribute as part of their land title would continue to do so, but no one could demand extra tribute from them because they were Christians. At the same time they would be exempt from financial or corvée labour contributions for the monasteries.

The settlement addressed the main social issues that had troubled the Tibet mission since its foundation. In that respect, it marked an end to a distinct period in the mission's history. However, it provided no more than an interim respite. In 1905 the M.E.P. was beset by an even worse calamity in the form of an uprising, starting in Bathang, that led to the murder of five missionaries, and formed part of the background to Zhao Erfeng's subsequent military campaign in Kham. ${ }^{41}$ For the purposes of this paper, these events belong to a different era.

\section{Conclusion: Global Forces and Local Responses}

Throughout the nineteenth and early twentieth centuries the M.E.P. retained the hope that they would one day be able to build a church in Lhasa. In that respect the broad contours of their vision of 'Tibet' remained unchanged: it always encompassed the whole of the territories of the Ganden Phodrang 
and, from the 186os onwards, came to include the Tibetan polities in Sichuan and Yunnan as well. Nevertheless, for the M.E.P., the political boundary between 'Tibet proper' and 'Chinese Tibet' proved to be a hard border, not a soft one. The establishment of the Padong mission in India was a reaffirmation of their dreams of reaching Lhasa, but never became more than a geographical anomaly. Although they would never have accepted the term, the 'Vicariate of Tibet' in practice became the 'Vicariate of Kham'. To take the irony a step further, it could even be argued that, by establishing his headquarters in Dartsedo, Bishop Chauveau anticipated the 1928 creation of Xikang Province, which centred on the same town (see Stéphane Gros' Introduction, this volume).

The history of the M.E.P. in the second half of the nineteenth century reflects the tensions between the missionaries' aspiration to bring Christianity to Central Tibet and their own confinement to the borderlands. In pursuit of the broader vision they promoted all possible agents of change, including advocating the Western powers' economic expansion into Tibet proper.

As has been seen, when the missionaries were the only Europeans in Tsarong in the 1850s, Renou was already able to report on the effects of growing Western economic influence. The M.E.P. hoped to accelerate this process of change by advocating more direct British and French political and economic engagement, thus creating more favourable conditions for the 'doctrine that leads to heaven'. In this project they clearly had limited success. The main reasons included the Lhasa authorities' fear of European expansion, their continuing influence on the Tibetan monasteries outside their formal authority in western Sichuan and Yunnan, and the limitations of Qing power in the borderlands. French pressure on the Beijing administration therefore translated into no more than a qualified degree of local protection for the missionaries.

Alongside their wider geopolitical ambitions, the M.E.P. were also intensely local. Indeed, to the extent that they changed people's lives, this was primarily at the parochial level among the villagers of Yerkalo and other settlements. In endeavouring to provide secure livelihoods for their followers through agriculture and trade, they struggled with the same geographical and ecological constraints as their neighbours. Unable to survive in isolation, they sought the support, or at least the acquiescence, of whichever political authorities would listen. In this approach they followed a pattern not so different from that of the Buddhist monasteries for centuries before them.

The M.E.P. fathers certainly started as aliens and, from the perspective of Lhasa as well as the Qing mandarins, they always remained so. 
However, in agricultural settlements such as Yerkalo and Cigu, as well as the markets of Adunzi and Dartsedo, they gradually became part of the fabric of local society. By the end of the century, to evoke the title of Lipman's (1997) work on the Muslims of northwest China, they had become 'familiar strangers', even if they would never have qualified as 'familiar Khampas'.

\section{Glossary of Chinese and Tibetan Terms}

$\begin{array}{ll}\text { Bathang } & \text { 'Ba' thang } \\ \text { Ba Chöde } & \text { 'Ba' chos sde dga' ldan phan bde gling (full name) } \\ \text { Bonga } & \text { Ba nga } \\ \text { Bongmé } & \text { 'Bum nye } \\ \text { Cigu } & \text { 茨姑 var. Tsekou } \\ \text { Chamdo } & \text { Chab mdo } \\ \text { Dartsedo } & \text { Dar rtse mdo (Tib.), Dajianlu 打箭炉(Ch.), var. } \\ & \text { Tatsienlou, Tachienlu. Now Kangding 康定. } \\ \text { depa } & \text { sde ba } \\ \text { detsodunpo } & \text { Sde tsho bdun po } \\ \text { Döndrupling } & \text { Don grub gling (Tib.), Dongzhulin si 东竹林寺 (Ch.) } \\ \text { Ganden Phodrang } & \text { Dga' ldan pho brang } \\ \text { Jizu } & \text { Ri bya rgya rkang chen (Tib.), Jizu Shan 鸡足山 (Ch.) } \\ \text { Lithang } & \text { Li thang } \\ \text { Markham } & \text { Smar khams } \\ \text { Menkong } & \text { Sman khang } \\ \text { mutekpa } & \text { mu stegs pa } \\ \text { Tsarong } & \text { Tsha rong } \\ \text { Tsewang } & \text { Tshe dbang } \\ \text { Yaregong } & \text { Yar ri sgang } \\ \text { Yerkalo } & \text { Yar kha logs (Tib.) (alt. Tsa kha logs), Yanjing 盐井 } \\ & \text { (Ch.). }\end{array}$

\section{References}

\section{Archival sources}

Archives Diplomatiques de Nantes (A.D.N.)

- Pékin 37. 'Dossiers Mission du Thibet' de 1846 à 1912. 
Archive des Missions Étrangères de Paris (A.M.E.P.). Paris

- Tibet letters: Files No 556 A-J.

- Pierre Giraudeau (1850-1941) Correspondence. File No. 1378.

- Francis Goré (1880-1954). Typescript papers. Une mission thibétaine (Yerkalo). Éphémérides de Notre Dame de Sacré-Coeur 1865-1922.

- Pierre-Marie Bourdonnec (1859-1905) 'Une histoire tibétaine à ne pas oublier'. Typescript of letters to Bourdonnec's family.

\section{Published sources}

Anon. c. 1905. 'Mgr Biet, vicaire apostolique du Thibet, 1838-19o1'. Les Contemporains 760.

Baber, Edward Colborne. 1882. Travels and Researches in Western China. London: John Murray.

Bensacq-Tixier, Nicole. 2003. Dictionnaire du corps diplomatique et consulaire français en Chine (1840-1911). Paris: Les Indes Savantes.

Bertsch, Wolfgang. 2009. 'The Use of Tea Bricks as Currency among the Tibetans'. Tibet Journal 34 (2): 35-80.

Booz, Patrick. 2011a. 'Tea, Trade and Transport in the Sino-Tibetan Borderlands'. DPhil thesis. Oxford University.

Booz, Patrick. 2011b. 'Fear of Indian Tea and the Failure of British India to Break the Chinese Tea Monopoly in Tibet'. In Buddhist Himalaya, vol. 1, edited by Alex McKay and Anna Balikci-Denjongpa, 277-29o. Gangtok: Namgyal Institute of Tibetology.

Bousquet, François. 2010. 'L'esprit de famille” des Missions Étrangères de Paris: les Monita ad Missionarios de 1665'. In La Société des Missions Étrangères de Paris. 350 ans à la rencontre de l'Asie, edited by Catherine Marin, 173-182. Paris: Karthala.

Bray, John. 1997. 'French Catholic Missions and the Politics of China and Tibet 1846-1865'. In Tibetan Studies. Proceedings of the 7 th Seminar of the International Association of Tibetan Studies, Graz 1995, vol. 1, edited by Helmut Krasser et al., 83-95. Vienna: Verlag der Österreichischen Akademie der Wissenschaften.

Bray, John. 2014. 'Christian Missionary Enterprise and Tibetan Trade'. In Trade, Travel and the Tibetan Border Worlds. Essays in Honour of Wim van Spengen (1949-2013), edited by Emilia Roza Sulek, John Bray, and Alex McKay. Tibet Journal 39 (1): 11-37.

Coleman IV, William M. 2014. Making the State on the Sino-Tibetan Frontier: Chinese Expansion and Local Power in Batang, 1842-1939. PhD dissertation. Graduate School of Arts and Sciences, Columbia University.

Cooper, T.T. 1868-1869. 'Letter from Mr. T.T. Cooper on the Course of the Tsan-po and Irrawaddy and on Tibet'. Proceedings of the Royal Geographical Society 13: 392-395 
Cooper, T.T. 1871. Travels of a Pioneer of Commerce. London: John Murray.

Desgodins, Auguste. 1864. 'Conversion de plusieurs villages'. Annales de la Propagande de la Foi 36: 313, 325 .

Desgodins, Auguste. c. 1881. A Tea Trade with Thibet. Darjeeling: Bengal Secretariat Press.

Desgodins, C.-H. ed. 1872. La Mission du Thibet de 1855 à 1870 . Verdun: Ch. Laurent. Deshayes, Laurent. 2008. Tibet (1846-1952). Les missionnaires de l'impossible. Paris: Les Indes savantes.

Engelhardt, Isrun. 2005. 'Between Tolerance and Dogmatism: Tibetan Reactions to the Capuchin Missionaries in Lhasa, 1707-1745'. Zentralasiatische Studien 34: 55-97.

Gill, Captain William. 1883. The River of Golden Sand. London: John Murray.

Groffier, Valérien. 1893. 'Travaux géographiques et scientifiques des missionaires Catholiques en 1893'. Bulletin de la Société de géographie de Lyon 12: 129-163.

Gros, Stéphane. 1996. 'Terre de confins, terres de colonisation. Essai sur les Marches sino-tibétaines du Yunnan à travers l'implantation de la Mission du Tibet'. Péninsule 33 (2): 147-208.

Gros, Stéphane. 2001. 'Ritual and Politics: Missionary Encounters with Local Culture in Northwest Yunnan'. Paper presented at the Association of Asian Studies Annual Meeting, 22-25 March 2001.

Gros, Stéphane. 2016. 'Tricks of the Trade: Debt and Imposed Sovereignty in Southernmost Kham in the Nineteenth to Twentieth Centuries'. Cross-Currents: East Asian History and Culture Review 19: 147-173. E-Journal. https://cross-currents. berkeley.edu/e-journal/issue-19/gros. Accessed 7 June 2019.

Guennou, Jean. 1986. Missions Étrangères de Paris. Paris: Fayard.

Launay, Adrien. 1905. Histoire de la Mission du Thibet. 2 vols. Paris: Desclée, De Brouwer et Cie.

Lipman, Jonathan N. 1997. Familiar Strangers: A History of Muslims in Northwest China. Seattle: University of Washington Press.

Marin, Catherine, ed. 2010. La Société des Missions Étrangères de Paris. 350 ans à la rencontre de l'Asie, 1658-2008. Paris: Karthala.

Michaud, Jean. 2007. 'Incidental' Ethnographers. French Catholic Missionaries on the Tonkin-Yunnan Frontier, 1880-1930. Leiden: Brill.

Moussay, Gérard, ed. 2007. Les Missions Étrangères en Asie et dans l'océan Indien. Paris: Les Indes savantes/Missions Étrangères de Paris.

Petech, Luciano. 1952-1957. I Missionari Italiani nel Tibet e nel Nepal. 7 vols. Rome: Instituto Poliografico dello Stato.

Relyea, Scott. 2016. 'Victorianizing Guangxu: Arresting Flows, Minting Coins, and Exerting Authority in Early Twentieth-Century Kham'. Cross-Currents: East Asian History and Culture Review 19:123-146. E-Journal. https://cross-currents. berkeley.edu/e-journal/issue-19/relyea. Accessed 24July 2019. 
Singh, Amar Kaur Jasbir. 1988. Himalayan Triangle. London: British Library.

Soulié, Jean-André. 1904. 'Géographie de la principauté de Batang'. La Géographie 9:87-104.

Tsomu, Yudru. 2015. The Rise of Gönpo Namgyel in Kham: The Blind Warrior of Nyarong. Lanham: Lexington Books.

Tsomu, Yudru. 2016. 'Guozhuang Trading Houses and Tibetan Middlemen in Dartsedo, the "Shanghai of Tibet"'. Cross-Currents: East Asian History and Culture Review 19: 71-121. E-Journal. https://cross-currents.berkeley.edu/e-journal/ issue-19/tsomu. Accessed 7 June 2019.

Young, Ernest P. 2013. Ecclesiastical Colony: China's Catholic Church and the French Religious Protectorate. New York: Oxford University Press.

\section{About the Author}

JOHN BRAY is an independent scholar currently based in Singapore. His research interests focus on the history of Christian missions and Western engagement with Tibet since the seventeenth century. His most recent publications include articles in Buddhist-Christian Studies, Bulletin of Tibetology, Rivista degli Studi Orientali, Tibet Journal and Zentralasiatische Studien as well as an edited collection, Art and Architecture in Ladakh (Brill, 2014, with Erberto Lo Bue). He was President of the International Association for Ladakh Studies (IALS) from 2007 to 2015. He is a member of the Editorial Board of Himalaya. Journal of the Association for Nepal and Himalayan Studies. 